Research

\title{
Application of multivariate statistical analysis and water quality index for quality characterization of Parbati River, Northwestern Himalaya, India
}

\author{
Gaurav Sharma ${ }^{1} \cdot$ Renu Lata $^{1} \cdot$ Nandini Thakur $^{1} \cdot$ Vishal Bajala $^{2} \cdot$ Jagdish Chandra Kuniyal $^{3} \cdot$ Kireet Kumar $^{3}$
}

Received: 4 May 2021 / Accepted: 12 August 2021

Published online: 22 September 2021

(c) The Author(s) $2021 \quad$ OPEN

\begin{abstract}
The present study is an attempt to accomplish the understanding of the factors impacting Parbati river water quality in Kullu district of Himachal Pradesh. The main objective is to assess the overall water quality, to explore its hydrogeochemical characteristics including major ion contents and other chemical parameters using Water Quality Index (WQI), statistical techniques (principal component analysis) and conventional graphical representation such as Piper trilinear diagram, Durov. Eighteen surface water samples were collected from different altitudinal sites to analyze physico-chemical parameters for June 2019 and September 2019. Analytical outcomes of thirty-six surface water samples collected in Pre-monsoon and Post-monsoon seasons are well within the permissible limits as per BIS, 2012 and WHO 2011 for drinking and domestic purposes. Water quality characterization for the assigned use shows that maximum surface water samples fall under excellent to good water quality index and are suitable for drinking without conventional treatment. The Piper trilinear diagram classified $100 \%$ of surface water samples for both seasons' falls in the fields of $\mathrm{Ca}^{2+}-\mathrm{Mg}^{2+}-\mathrm{HCO}_{3}{ }^{-}$water type indicating temporary hardness. Abundance of ions in the water samples is in the order: anions $\mathrm{HCO}_{3}{ }^{-}>\mathrm{Cl}^{-}>\mathrm{SO}_{4}{ }^{2-}>\mathrm{NO}_{3}{ }^{-}$ and cations $\mathrm{Mg}^{2+}>\mathrm{Ca}^{2+}>\mathrm{Na}^{+}>\mathrm{K}^{+}$. PCA identifies that the surface water chemistry is influenced by natural factors as well as minor anthropogenic activities in both the seasons. The correlation matrix has been prepared to analyse and observe the significance of the factors on the assessment of river water quality. Periodic assessment of surface water samples of the Parbati river and adjoining areas should be carried out. This approach will help in finding out any contamination of water occurring due to rapid socio-economic development as well as explosion of tourism industry in the region. Present study will work as baseline database for any future work in the region.
\end{abstract}

Keywords Water quality · Hydrogeochemical characteristics · Water quality index · Principal component analysis · Piper trilinear diagram · Anthropogenic activities

\section{Introduction}

Rivers form key role in sustainable socio-economic development of a country and account for $0.006 \%$ of the freshwater resources in the world [1,2]. The Himalayan rivers are under immense stress due to exponential population growth, industrialization, agriculture and urbanization. These anthropogenic effects combined with uncertain effects of climate change raising serious concerns on rivers both in terms of quality and quantity [3-5]. The people of Himalayan region

$\triangle$ Renu Lata, renu15_negi@yahoo.co.in; Jagdish Chandra Kuniyal, jckuniyal@gmail.com | 'G.B. Pant National Institute of Himalayan Environment, Himachal Regional Centre, Mohal-Kullu, Himachal Pradesh, India. ${ }^{2}$ Department of Environment Studies, Panjab University, Chandigarh, India. ${ }^{3}$ G.B. Pant, National Institute of Himalayan Environment, Kosi-Katarml, Almora, Uttrakhand, India.

Discover Water $\quad$ (2021) 1:5 | https://doi.org/10.1007/s43832-021-00005-3 
are dependent on river water and groundwater for drinking, irrigation and other domestic purposes [6] and some towns are major tourist destinations hosting large population during peak tourist season. The discharge of untreated or partly treated sewage in river and poor waste management practices especially along the bank is deteriorating quality of river which sequentially also affecting the ground water quality in adjoining areas [7] Water portability is significantly dependent on its quality which is determined and controlled by its geochemistry in natural conditions $[8,9]$ whereas pollution in water is also dependent on seasonal variation in precipitation, surface runoff, interflow, groundwater flow from bacterial contamination and toxic elements due to their origin from anthropogenic activities [10]. Developing countries like India are more prevalent to degradation of river water quality where millions of people reside on the river banks with poor sewerage system. Therefore, it is essential to monitor water quality as it is directly related with human health and approximately $21 \%$ of communicable diseases are water related as per World Bank estimation $[11,12]$.

Climate changes have laid impact as there is a profound glacier retreat which has resulted in fresh water scarcity in Indian Himalayan Region (IHR) [13]. Similarly unprecedented urbanization, increased tourism, changing land use pattern, waste disposal and agricultural runoff are the main casual factors other than natural factors affecting the water quality of rivers in the Himalayan region [6, 14]. Parts of Kullu district in Himachal Pradesh are facing the water shortage due to changing climatic conditions and other anthropogenic activities $[15,16]$.

Studies on surface and groundwater monitoring with respect to WQI has been done by various researchers [17-19]. Water chemistry is constrained by various hidden factors related to natural and anthropogenic influences that are hard to comprehend and decipher significant data using simple techniques [20, 21]. In this study physicochemical properties of 36 water samples collected in pre-monsoon and post-monsoon from different altitudinal sites were analyzed to compare with standards given by Bureau of Indian Standards (BIS) and World Health Organization (WHO) for drinking and domestic purposes and water quality index is generated using compound data set to evaluate and assess the disparity in overall quality among study sites and seasons.In addition to the WQI and hydro geochemical analysis, the multivariate statistical approaches were used to understand complex information grids of water quality for efficient management and identification of effective solutions to pollution problems [22, 23]. Therefore, the findings of study will provide significant information of surface water quality of river Parbati and will help to adopt quality aspect of water in a judicious and sustainable manner.

\section{Study area}

The study area lies in Parbati valley in Kullu district of Himachal Pradesh. River Parbati is the main flowing river draining an area of $1938 \mathrm{~km}^{2}$ in the valley and the basin extends between $31^{\circ} 50^{\prime} \mathrm{N}$ and $32^{\circ} 05^{\prime} \mathrm{N}$ latitude and $77^{\circ} 05^{\prime} \mathrm{E}$ and $77^{\circ} 50^{\prime}$ E longitude (Fig. 1). It originates from Mantalai glacier at an altitude of $5200 \mathrm{~m}$ amsl and below Pin Parbati pass on the western slope of the Greater Himalaya and traverse down through complex topography into the River Beas at Bhunter $(1096 \mathrm{~m})$. River Parbati is fast flowing, several small tributaries join at almost every angle outlining dendritic pattern. However, the valley is tourist hotspot as it is rich in art and culture, white-capped snowy peaks, dense green forest, dazzling rivers, hot water springs and sacred places. The climate is generally cool and dry whereas annual rainfall is $1405 \mathrm{~mm}$ out of which $57 \%$ occurs from June to September [24].

\subsection{Geology and hydrogeology}

The area under investigation comprises of Precambrian meta sedimentary now uncovered in the profoundly eroded "Kullu Rampur window" under the crystalline thrust sheets [25]. The geology of the area has been divided into three units, Manikaran quartzites, green bed member and Bhalan member under Banjar formation which includes various high-grade gneiss and schist, pegmatite, migmatite, granite and quartz veins along with carbonaceous phyllite, quartzite and limestone bands [26]. The exposed rock types around Manikaran and Kasol are white to grayish well jointed quartzites which are known as Manikaran quartzites [27]. The probable sources of high radioactivity in the area are due to intrusive tourmaline, whereas hot water emergence is through highly jointed and fractured quartzites at Manikaran and Kasol [24].The geology of the Parbati basin is represented in Fig. 2.

The Kullu district has two hydro geological units in the form of porous and fissured formations. Porous formation has unconsolidated sediments of terrace, valley fills and fluvial channel whereas fissured formations has 


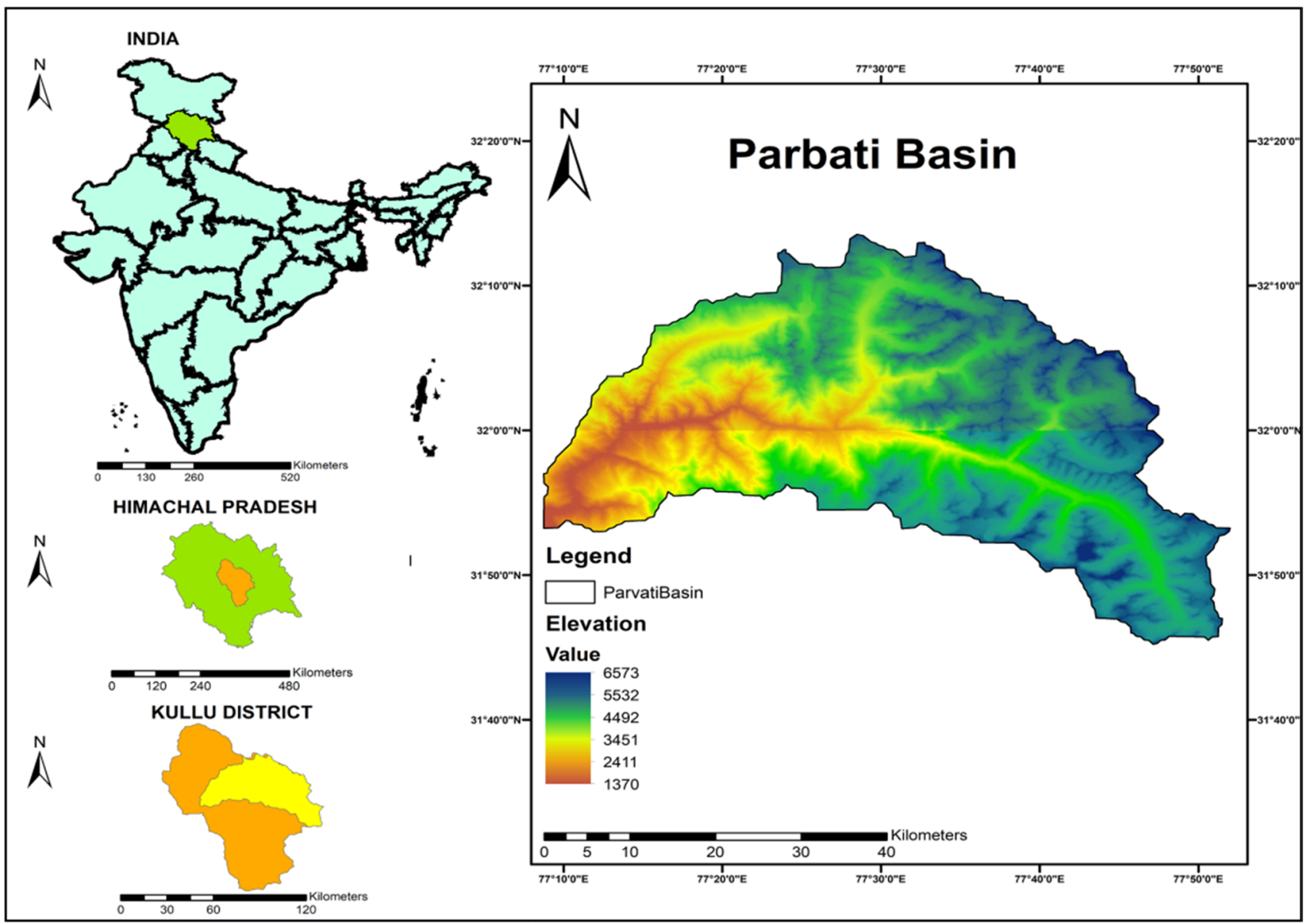

Fig.1 Location of the study area with altitude gradient

semi-consolidated to consolidated sediments of sedimentary, metamorphic and igneous origin descending higher to lower altitude [14]. The Parbati basin has fissured formation as shown in Fig. 2. The porous structures of unconsolidated sediments form the potential aquifers. The occurrence of groundwater in the basin is confined to semiconfined. However, phreatic aquifers form major source of domestic and irrigation water usages in the valley.

\subsection{Drainage pattern}

The Drainage pattern of the River Parbati exhibits tree-like dendritic pattern which is developed over sedimentary rocks (Fig. 2) [28]. Additionally, other drainage patterns are also present in the basin. Herringbone type of drainage pattern at Marhigarh Nala is one of the patterns where tributaries meet the mainstream at right angle. The trellis drainage pattern representing soft rocks like phyllitic slates and are well developed in the terrace and lower reaches of the valley [29]. In the areas of the uniformly dipping rocks, streams are running parallel to each other forming sub parallel drainage pattern. The sampling location in the study area is represented in Fig. 3.

\section{Materials and methods}

A well approached Stratified sample technique was adopted to collect the surface water sample along the river stretch of the study area. Total of thirty-six water samples, eighteen samples during pre-monsoon (June 2019) and eighteen samples during post-monsoon (September 2019) were collected from river Pārbati and its tributaries. 


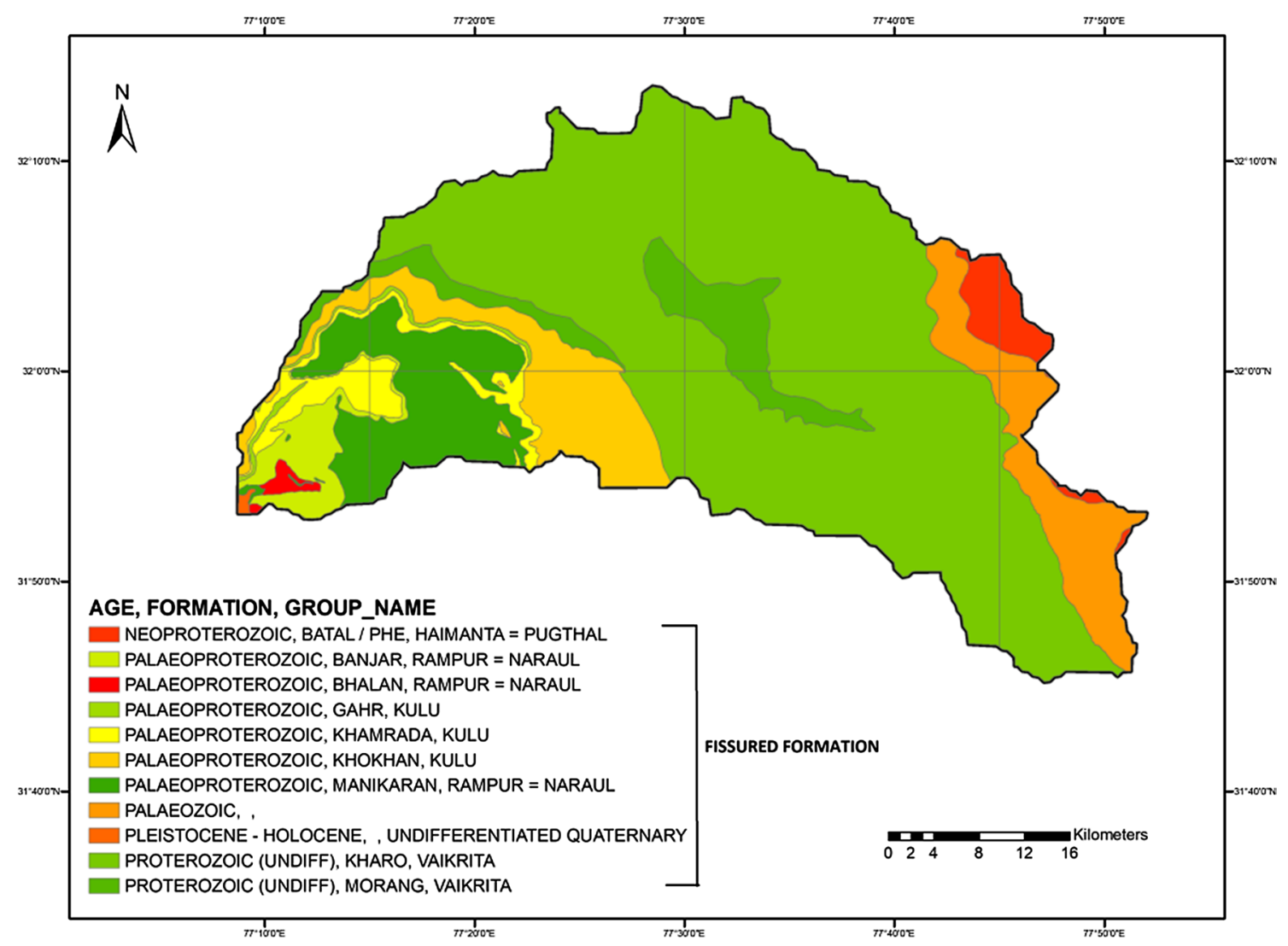

Fig.2 Geological map of Parbati Basin

Samples were collected in $1000 \mathrm{ml}$ best quality, sealed shut polyethylene bottles with cover lock. Physical parameters like EC, pH, TDS were measured on the field after sample collection using portable water and soil analysis kit. Major cations $\left(\mathrm{Ca}^{2+}, \mathrm{Mg}^{2+}, \mathrm{Na}^{+}, \mathrm{K}^{+}\right)$and anions $\left(\mathrm{HCO}_{3}{ }^{-}, \mathrm{Cl}^{-}, \mathrm{SO}_{4}{ }^{2-}, \mathrm{NO}_{3}{ }^{-}\right)$were analyzed by following standard procedure given by American Public Health Association [30]. The accuracy of the chemical analysis was checked by Charge Balance Error (CBE) [31].

$$
\text { Charge Balance Error }(\mathrm{CBE})=\left(\sum \text { Cations }-\sum \text { Anions }\right) /\left(\sum \text { Cations }+\sum \text { Anions }\right) \times 100 \%
$$

Majority of the analyzed samples showed CBE around $\pm 10 \%$

Calcium, Magnesium, Bicarbonates and Total hardness were determined using EDTA titrimetric method by APHA 2017. Sodium and Potassium using flame photometric method, Nitrate and Sulphate by UV spectrophotometric method respectively. Chloride was estimated through argentometric method and alkalinity with acid titration method. Mean values were calculated for each parameter to understand the seasonal variation as an indication of the precision of each parameter. Maps were prepared using ArcGIS 10.8 software and Piper trillinear, Durov were plotted using Grapher. The statistical software SPSS, Grapher, Aquachem and Microsoft Excel were employed for the calculations and data interpretation.

\subsection{Appraisal of Water Quality Index (WQI)}

WQI is an effective mathematical tool to evaluate the suitability of water for drinking purpose [32]. It is calculated by adopting the weighted arithmetical index method [33]. In the present study physiochemical parameters namely $\mathrm{pH}$, 


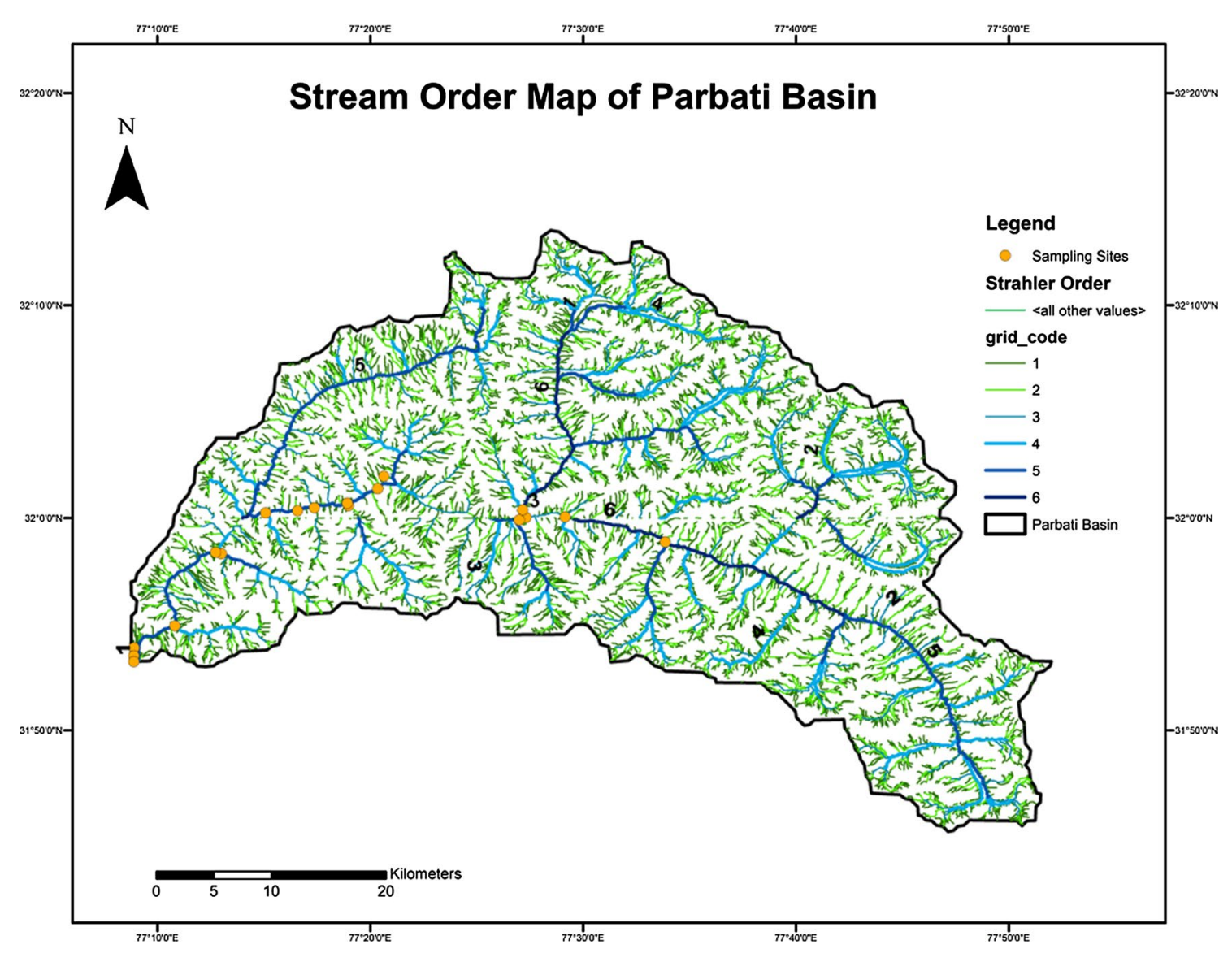

Fig.3 Drainage pattern and sampling sites of the Parbati River Basin

$\mathrm{EC}, \mathrm{TDS}, \mathrm{TH}, \mathrm{Ca}^{2+}, \mathrm{Mg}^{2+}, \mathrm{Cl}^{-}, \mathrm{SO}_{4}{ }^{2-}, \mathrm{NO}_{3}{ }^{-}$were considered for computing WQI for river Parbati. The weighted arithmetic index method was adopted by many researchers $[34,35]$ and the equation used is,

$$
\mathrm{WQI}=\sum \mathrm{qn} W n / W n
$$

where $\mathrm{W}_{\mathrm{n}}=$ unit weight of $\mathrm{nth}$ parameters, $\mathrm{q}_{\mathrm{n}}=$ sub-index or quality rating for the ith parameter.

The calculation of WQI involves following steps (Eq. 3-5):

$$
W_{n}=\mathrm{K} / \mathrm{Sn}
$$

$\mathrm{K}$, is the proportionality constant obtained from,

$$
\mathrm{K}=\left[1 /\left(\sum \mathrm{ni}=01 / S i\right)\right][1 /
$$

where, Sn and Si are the BIS (Bureau of Indian Standards) standard values of the water quality parameter

$$
\mathrm{q}_{\mathrm{ni}}=\mathrm{Va}-\mathrm{Vi} / \mathrm{Vs}-\mathrm{Vi} \times 100
$$

$\mathrm{q}_{\mathrm{ni}}$ is the quality rating of the ith parameter for a total of $\mathrm{n}$ water quality parameters.

Where, $\mathrm{Va}=$ value of the water quality parameter obtained from laboratory analysis, $\mathrm{Vi}=$ ideal value (for $\mathrm{pH}=7$ and 0 for other parameters) and Vs = BIS standard value of water quality parameters. 


\subsection{Evaluation of hydrogeochemical facies of surface water}

To comprehend the hydro geochemical attributes of surface water, different plots were utilized specifically, Piper, Durov and Gibbs plot [36-38]. These plots represent the graphical relationship characterizing different geochemical marks in surface water samples. The Grapher 12.0 was used to prepare the Piper diagram and Durov, while Gibbs plot was prepared by Aquachem software.

\subsection{Multivariate statistical analysis}

Multivariate Statistical techniques have been used to organize and simplify datasets and characterize freshwater, marine water and sediment quality [39-41]. In recent years, water quality assessment has been widely done using multivariate statistical techniques $[42,43]$.

Correlation analysis is a technique which determines the correlation coefficient between variables. The relationship between two variables can be measured by the strength and significance of the variables. The strength is indicated by the correlation ( $r$ ), whereas the significance is expressed in probability levels ( $p$ values). Larger the correlation coefficient, stronger the relationship, whereas smaller the $p$ level, more significant the relationship.

Statistical extraction of linear relationship from a given set of variables is performed by applying Principal Component Analysis (PCA) technique [22]. PCA allows to gain insight into the data without significant loss of information in the process $[44,45]$. Principal components generated during the analysis are arranged in such a manner that they correspond to decreasing contribution of variance, i.e., principal component 1 (PC1) explains the highest amount of variance in the original data $[46,47]$ classified the factor loadings as "strong", "moderate" and "weak", corresponding to absolute loading values of $0.75,0.75-0.50$ and $0.50-0.30$, respectively. However, loading reflects the relative importance of a variable within the component and does not reflect the importance of the component itself [48].

Cluster analysis was performed to arrange large data set of data into groups on the basis of given set of characterstics. Cluster analysis identifies relatively homogeneous groups or cluster of sampling sites based on their similarities/ dissimilarities [49]. In this study dendogram was obtained by performing wards method using squared Euclidean distance as a measure of similarity.

The datasets adequacy for PCA was calculated by the Kaiser-Meyer-Olkin Test (KMO) and Bartlett's test [50]. A KMO value of 0.5 is considered the smallest value acceptable and high values near to 1 indicates usefulness of PCA in the study.

\section{Results and discussion}

Statistical summary of river water samples analyzed for various physio-chemical parameters is given in Table 1 with permissible limits prescribed by BIS and WHO [51,52]. Mean value for all physio-chemical parameters, except $\mathrm{Ca}^{2+}{ }^{2} \mathrm{Na}^{+}$, $\mathrm{K}^{+}$and $\mathrm{Cl}^{-}$, were showing higher values during the pre-monsoon period than post-monsoon.; EC accounted for $100 \%$ within desirable limit with mean values 93.44 and $81.05 \mu \mathrm{S} / \mathrm{cm}$ during the period of investigation. TDS values were well within desirable limit in both seasons with mean values 58.8 and $51.06 \mathrm{mg} / \mathrm{L}$. The average values of total hardness are $95.36 \mathrm{mg} / \mathrm{L}$ in pre-monsoon and $83.44 \mathrm{mg} / \mathrm{L}$ in post-monsoon, respectively. Classification of river water based on total hardness [53] and total dissolved solids [54] are shown in Table 2. Further during the lab analysis higher soluble concentration of $\mathrm{Ca}^{2+}, \mathrm{Mg}^{2+}$ and $\mathrm{HCO}_{3}{ }^{-}$ions was found which may contribute to increased hardness of river water samples. Magnesium accounted for $12.62 \mathrm{mg} / \mathrm{L}$ in pre-monsoon and $8.85 \mathrm{mg} / \mathrm{L}$ for post-monsoon representing samples within desirable limits as the calcium starts precipitating after super saturation has been attained the dissolved concentration of magnesium exceeds that of calcium. Weathering of sandstone and dolomite, in the study area, accounts for higher concentration of $\mathrm{Mg}^{2+}$ found during the analysis [55]. Mean value of $\mathrm{HCO}_{3}{ }^{-}$was more significant during pre-monsoon due to dissolution of carbonate rocks, weathering of feldspar by carbonic acids and oxidation of $\mathrm{NO}_{3}{ }^{-}$and $\mathrm{SO}_{4}{ }^{2-}$ with organic matter as compared to post-monsoon [56]. The parameters like $\mathrm{Na}^{+}, \mathrm{K}^{+}, \mathrm{Cl}^{-}, \mathrm{NO}_{3}{ }^{-}, \mathrm{SO}_{4}{ }^{2-}$ and $\mathrm{Mg}^{2+}$ were all within the desirable range. During the pre-monsoon season the ionic dominance pattern in the water is governed by cationic species in the order of $\mathrm{Mg}^{2+}>\mathrm{Ca}^{2+}>\mathrm{Na}^{+}$and $\mathrm{K}^{+}$. However, during the post-monsoon season, such dominance of cations is exceeded by that of anionic species in the order of $\mathrm{HCO}_{3}{ }^{-}>\mathrm{SO}_{4}{ }^{2-}>\mathrm{NO}_{3}{ }^{-}>\mathrm{Cl}^{-}$. 


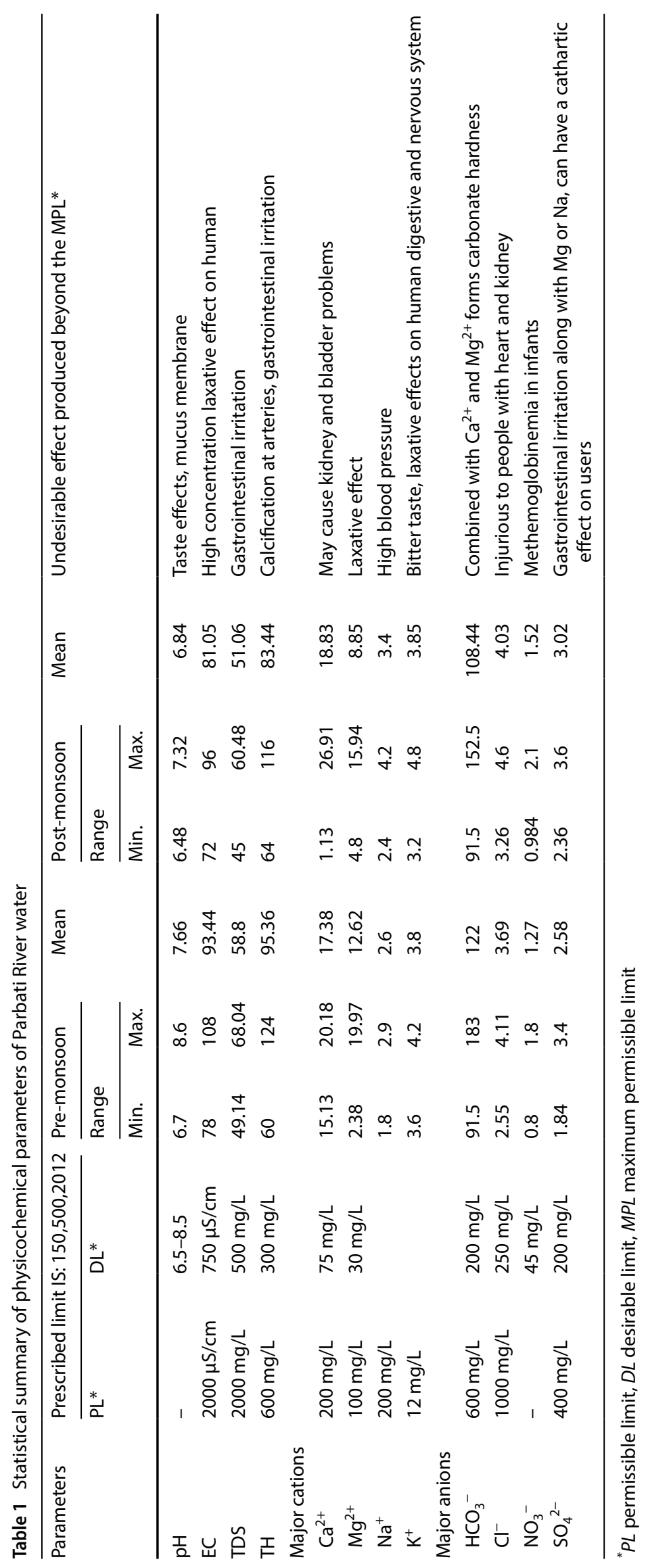




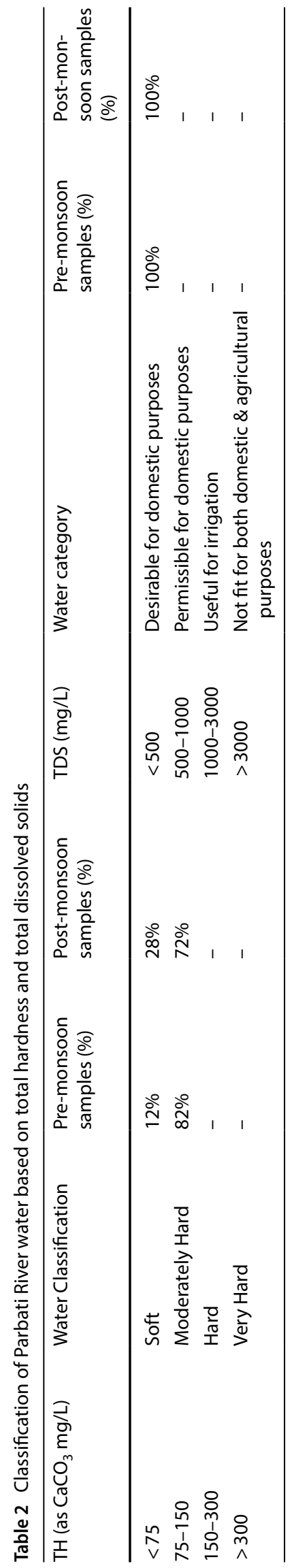




\subsection{Hydrogeochemical evaluation}

Hydrogeochemical facies layouts in the form of graphical representation aiming to provide the analogies, dissimilarities and interpretation of evolutionary trends and different type of water in a particular area. For studying the effects of mixing water within the different lithological frameworks and for understanding various geochemical processes the value of graphical representation techniques is of immense importance. Many researchers such as Piper, Chadha, Collins and Black have contributed to the concept of graphical representation of geochemical analysis of water [36, 57-59].

\subsubsection{Piper trilinear diagram}

Piper diagrams are widely applied to graphically study the sources of dissolved constituents in water samples [36]. The ionic concentration was plotted in piper diagram to characterize the hydrochemistry of surface water in the study area (Fig. 4a, b). Piper diagram shows that all the samples are in $\mathrm{Ca}^{2+}-\mathrm{Mg}^{2+}-\mathrm{HCO}_{3}{ }^{-}$facies belongs to temporary hardness and alkaline earth elements $\left(\mathrm{Ca}^{2+}+\mathrm{Mg}^{2+}\right)$ exceeding the alkali elements $\left(\mathrm{Na}^{+}+\mathrm{K}^{+}\right)$where $\mathrm{Ca}^{2+}$ and $\mathrm{Mg}^{2+}$ are leading cations in the study area shown in Table 3. Further, it was found that the concentration of weak acids $\left(\mathrm{CO}_{3}{ }^{2-}+\mathrm{HCO}_{3}{ }^{-}\right)$, during both the seasons, is higher than the strong acids $\left(\mathrm{SO}_{4}{ }^{2-}\right.$ and $\left.\mathrm{Cl}^{-}\right)$. This further indicates the presence of $\mathrm{HCO}_{3}{ }^{-}$as principal anion in the surface water. The Cation triangle shows that $16 \%$ samples are $\mathrm{Ca}^{2+}$ type, $56 \%$ in $\mathrm{Mg}^{2+}$ and remaining $28 \%$ falls in no dominant cation zone for pre monsoon (Fig. 3a), whereas in post monsoon $44 \%$ is dominating in $\mathrm{Mg}^{2+}$ zone, $33 \%$ in no dominating zone and $23 \%$ in $\mathrm{Ca}^{2+}$ type (Fig. 3b). The anion triangle exhibits that $\mathrm{HCO}_{3}{ }^{-}(100 \%)$ is the dominant ion during pre-monsoon and post-monsoon (Table 3). Consequently, concentration of ions such as $\mathrm{Na}^{+}, \mathrm{K}^{+}$and $\mathrm{Cl}^{-}, \mathrm{SO}_{4}{ }^{2-}$ is very low and thus insignificant in both the seasons. As all the samples fall within the field of $\mathrm{Ca}^{2+}-\mathrm{Mg}^{2+}-\mathrm{HCO}_{3}{ }^{-}$water type, we can infer that the surface water chemistry is controlled by leaching process of dolomites, limestones and gypsum.

\subsubsection{Durov plot}

Durov plot is a significant graphical structure that gives better data on the hydrochemical portrayal and possible geochemical processes (mixing, cation exchange, reverse ion exchange dissolution) influencing the water quality of the area. This diagram is a composite plot consisting of two ternary diagrams where the milli equivalents percentages of the cations of interest were plotted against that of anions of interest; sides form a central rectangular, binary plot of total cation vs. total anion concentrations [60]. This diagram is very useful in indicating the samples with similar chemical composition as well as determines a useful relationship among different water samples [61]. The Durov plot of the water

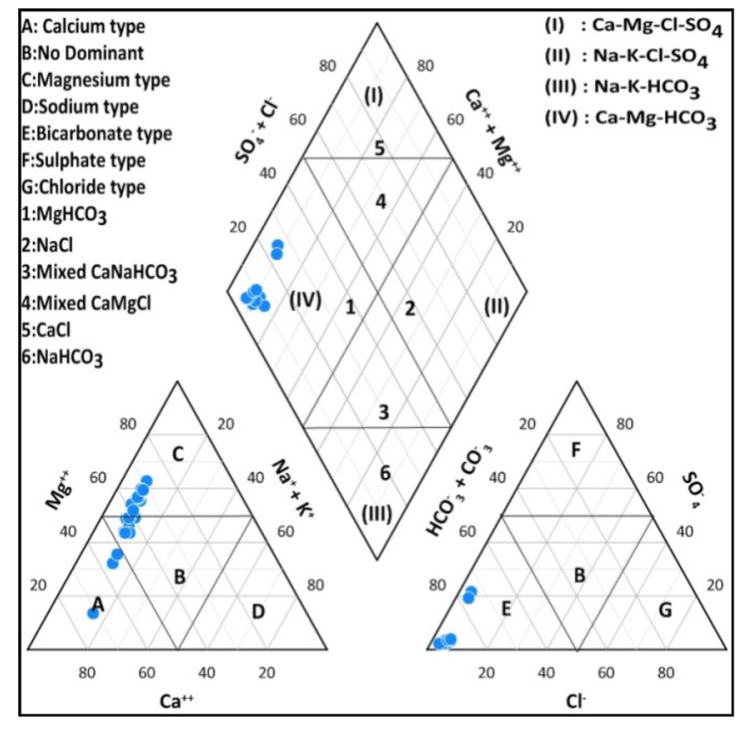

(a) Pre monsoon

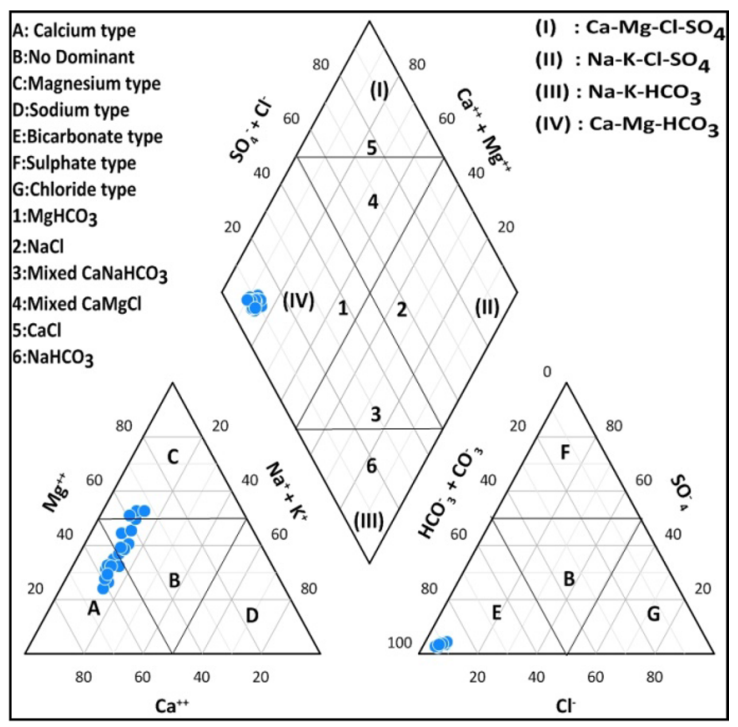

(b) Post monsoon

Fig. 4 Piper classification diagram illustrating the chemical composition of Parbati River water. a Pre monsoon. $\mathbf{b}$ Post monsoon 


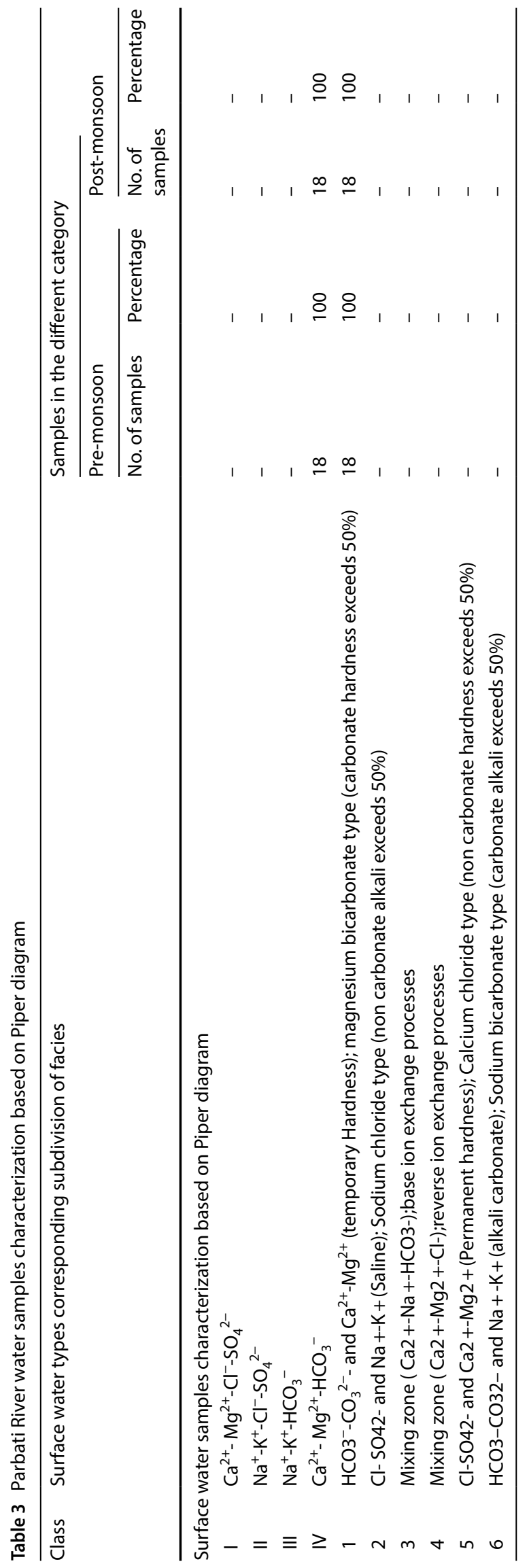


samples indicates that there are mainly two geochemical processes that could affect the genesis of water in the study area (Fig. 4a, b). According to the classification of [61], 88\% samples in Pre-monsoon and $86 \%$ in Post-monsoon belong to $\mathrm{HCO}_{3}{ }^{-}$and $\mathrm{Mg}^{2+}$ dominant cation, this water type indicates probable mixing, uncommon dissolution influences and reverse ion exchange process (Fig. $5 \mathrm{a}$ ) whereas $12 \%$ samples in pre-monsoon and $14 \%$ samples in post-monsoon falls where $\mathrm{HCO}_{3}{ }^{-}$and $\mathrm{Ca}^{2+}$ dominant type of water, indicating the partial ion exchange processes (Fig. 5b). None of the data points lie in the lower-right side of the boomerang, where water composition is dominated by atmospheric precipitation process.

\subsubsection{Gibbs plot}

Hydrochemical processes such as precipitation, rock water interaction and evaporation are well interpreted through gibbs plot [36]. Gibbs demonstrated that if total dissolved solid is plotted against $\mathrm{Na}+\mathrm{K} /(\mathrm{Na}+\mathrm{Ca}+\mathrm{K})$, it would provide information on the mechanism controlling chemistry of water. Collectively, the chemistry of water is influenced by the following three main factors: (1) evaporation dominance; (2) precipitation dominance and (3) rock dominance. Figure 6 exhibits that all the surface water samples for pre-monsoon and post-monsoon fall in the precipitation dominance zone which indicates that water is mainly controlled by rock dominance however geochemical process such as precipitation -dissolution; oxidation -reduction and ion exchange are the main governing factors of water chemistry.

The studies in other parts of Himalayan regions confirmed rock dominance as main factor for controlling ionic composition in water bodies $[6,62,63]$. In the study area due to long time rock water interaction, percolations and flow through the rocky lithology has resulted in high solute concentration which is significantly controlling the water quality of the area. However, during post monsoon there is minor influence of precipitation dominance and melting of ice in the region. This reflects that water chemistry is mainly controlled by interaction of rock formation with precipitation for both seasons in Parbati river.

\subsection{Water Quality Index}

The cumulative effect of various physio-chemical parameters governing the overall water quality is holistically represented in Water Quality Index (WQI). The weighted arithmetic index method [33] has been used for the calculation. WQI reveals variation in the water quality status related to suitability for human consumption. A perusal of Table 4 reveals that $22 \%$ water samples in pre-monsoon and $50 \%$ water samples in post monsoon season respectively fall in excellent class whereas $73 \%$ water samples in pre monsoon and $50 \%$ water samples in post-monsoon falling in good class. Water quality of the river water samples has $\mathrm{WQI}=<50$ which represents the excellent to good water quality of analyzed river water samples (Table 5). Most of the sampling locations meets the requirement of good water quality except in Bhunter during pre-monsoon. The Bhunter town is situated on banks of river Beas, due to incessant growth of population, modern infrastructure and small industries the water quality of the town maybe influenced by household and industrial wastewater followed by agricultural run-off. Along the altitudinal gradient, most of the upstream segments have excellent to

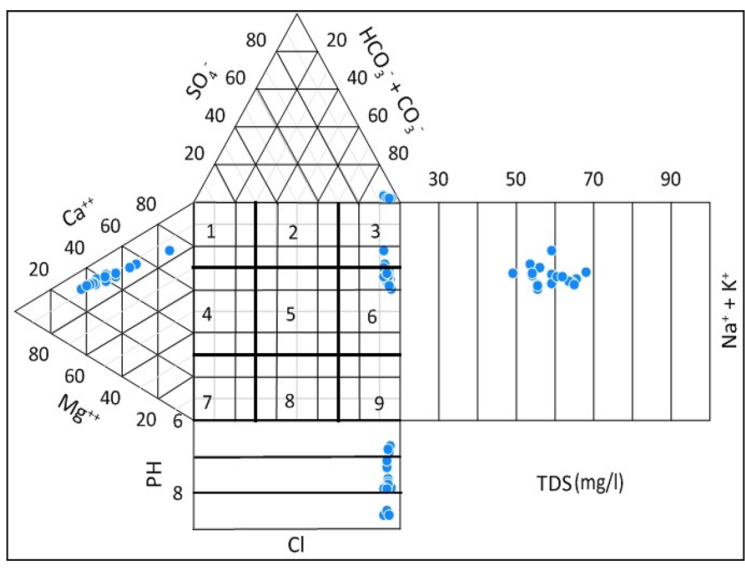

(a) Pre monsoon

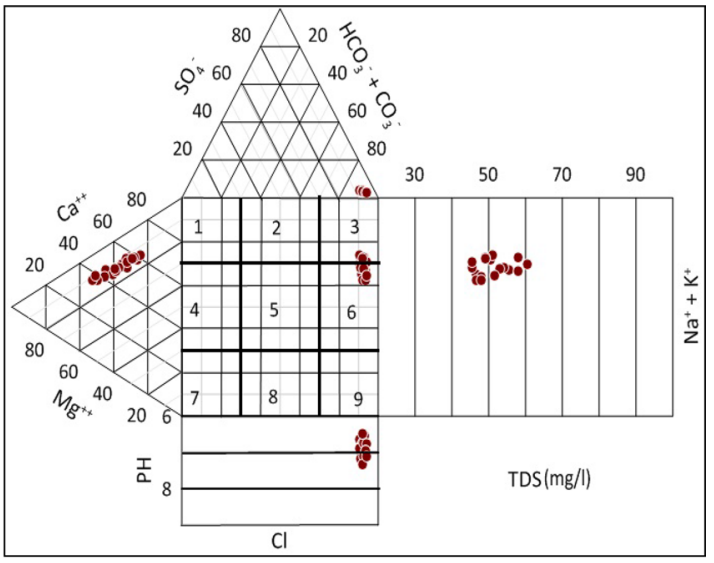

(b) Post monsoon

Fig. 5 Durov diagram showing the hydrochemical facies in the Parbati River water. a Pre monsoon. b Post monsoon 

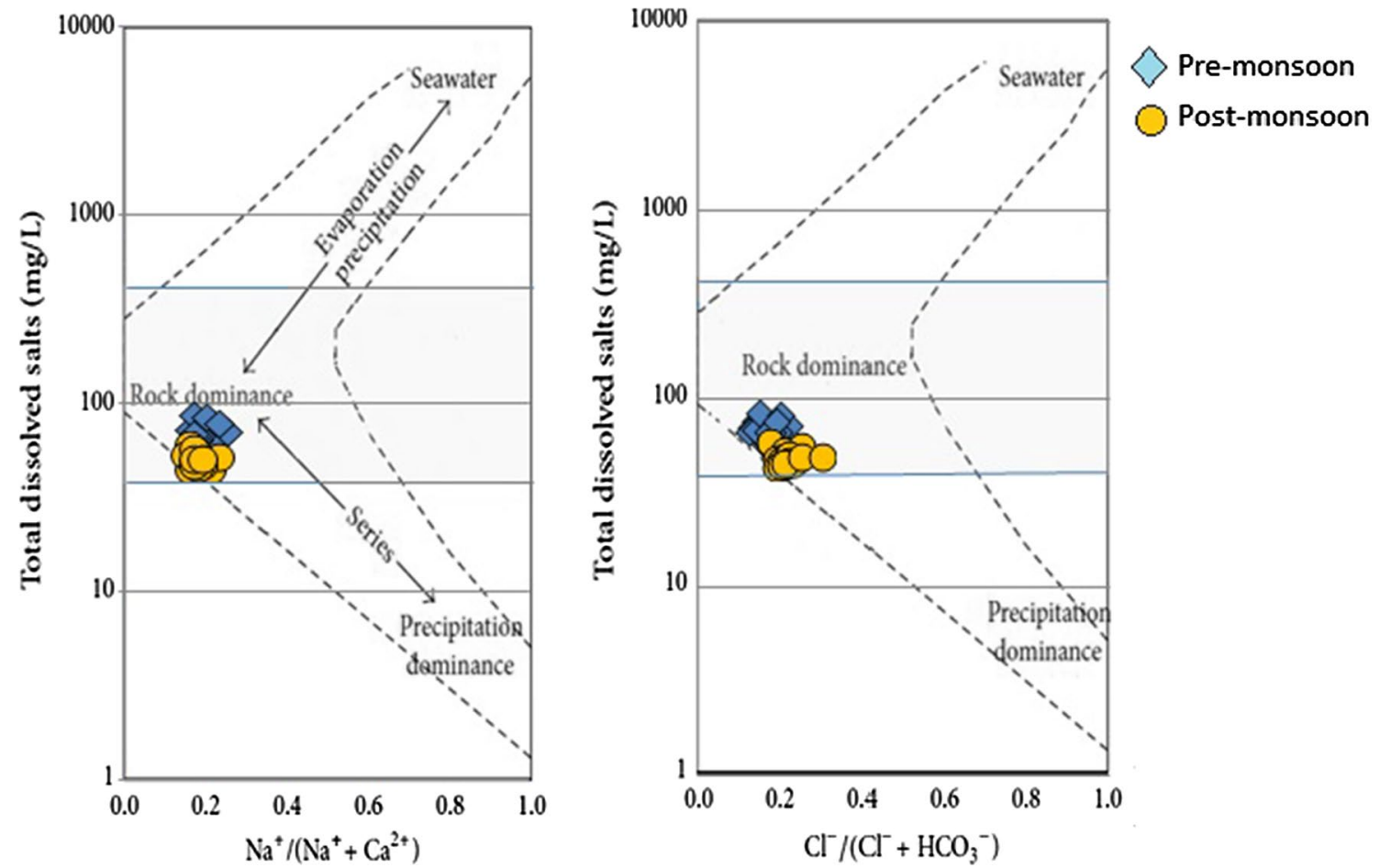

Fig. 6 Mechanism controlling water chemistry in Parbati River (after Gibbs [38])

Table 4 WQI categorization

\begin{tabular}{llllllll}
\hline Sr.No. & WQI & Status & & Pre-monsoon & & \multicolumn{2}{l}{ Post-monsoon } \\
& & & $\begin{array}{l}\text { Samples } \\
\text { (in numbers) }\end{array}$ & Percentage (\%) & & $\begin{array}{l}\text { Samples } \\
\text { (in numbers) }\end{array}$ & Percentage (\%) \\
\hline 1 & $0-25$ & Excellent & 4 & 22 & 9 & 50 \\
2 & $26-50$ & Good & 13 & 73 & 9 & 50 \\
3 & $51-75$ & Poor & 1 & 5 & - & - \\
4 & $76-100$ & Very poor & - & - & - & - \\
5 & $>100$ & Unfit & - & - & - & - \\
\hline
\end{tabular}

good water quality for both the seasons where as in downstream segments the influence of population and urbanization on water quality is deteriorating towards the lower altitudinal regions. The locations like Rudranag, Guwacha, Toshnalla and Grahan nalla have lesser change in their WQI values whereas Jiyah, Hathithan and Bhunter showed a maximum change in WQI values from pre-monsoon to post-monsoon indicating that runoff played important role in dilution of river pollutant in these areas.

\subsection{Correlation matrix}

The Pearson's correlation matrix develops relationship among components that how well the variance of each component can be explained through correlation with each of other [64]. A common origin and similar distribution must be defined to correlated variables in order to interpret the coefficient correlation. The value near to -1 or 1 in correlation coefficient depicts the strongest negative or strongest positive relationship between two variables whereas values closest to 0 denotes no linear relationship between variables.

The Pearson's correlation coefficient ( $r$ ) was prepared to assess correlation among $\mathrm{pH}, \mathrm{EC}, \mathrm{TDS}$, Hardness and various chemical constituents variables for surface water in pre-monsoon (June 2019) and post-monsoon (September 2019). Several parameters are found to be strong positive $(r>0.8)$ and positive correlated $(r>0.5-0.79)$. During pre-monsoon a 
Table 5 WQI Calculation for individual water sampling locations

\begin{tabular}{|c|c|c|c|c|c|}
\hline \multirow[t]{2}{*}{ S.No. } & \multicolumn{3}{|l|}{ Pre-Monsoon } & \multicolumn{2}{|c|}{ Post-Monsoon } \\
\hline & Locations & WQI Value & WQI Class & WQI Value & WQI Class \\
\hline 1 & Nhyarathach & 32.19 & Good & 22.48 & Excellent \\
\hline 2 & Rudranag & 21.44 & Excellent & 19.48 & Excellent \\
\hline 3 & Parvati river Guwacha & 20.30 & Excellent & 21.36 & Excellent \\
\hline 4 & Tosh nala & 24.73 & Excellent & 22.84 & Excellent \\
\hline 5 & Barshaini Tail pt & 26.62 & Good & 22.95 & Excellent \\
\hline 6 & Manikaran bridge & 33.76 & Good & 26.45 & Good \\
\hline 7 & Manikaran NHPC & 35.86 & Good & 23.65 & Excellent \\
\hline 8 & Grahan nalla & 24.51 & Excellent & 22.29 & Excellent \\
\hline 9 & Kasol & 39.66 & Good & 26.31 & Good \\
\hline 10 & Katagla & 37.55 & Good & 28.43 & Good \\
\hline 11 & Sumaropa & 34.21 & Good & 26.45 & Good \\
\hline 12 & Malana Jari & 36.64 & Good & 24.72 & Excellent \\
\hline 13 & Shat nalla & 37.00 & Good & 24.65 & Excellent \\
\hline 14 & Shat Parvati confluence & 36.09 & Good & 28.45 & Good \\
\hline 15 & Charod & 35.71 & Good & 32.34 & Good \\
\hline 16 & Jiyah & 49.08 & Good & 36.40 & Good \\
\hline 17 & Hathithan & 48.53 & Good & 32.45 & Good \\
\hline 18 & Bhunter(Confluence) & 53.42 & Poor & 38.45 & Good \\
\hline 19 & Overall Quality & 34.85 & Good & 26.67 & Good \\
\hline
\end{tabular}

strong positive correlation value exist between EC-TDS and TH- $\mathrm{Mg}^{2+}-\mathrm{HCO}_{3}{ }^{-}$whereas positive correlation observed in $\mathrm{TH}-\mathrm{Ca}^{2+}, \mathrm{Mg}^{2+}-\mathrm{HCO}_{3}{ }^{-}, \mathrm{Cl}^{-}-\mathrm{HCO}_{3}{ }^{-}$and $\mathrm{Na}^{2+}-\mathrm{HCO}_{3}{ }^{-}$indicating that these chemical parameters are from similar sources and can be attributed to geogenic process, while water traveling over sedimentary and metamorphic rocks which dissolve calcium, magnesium, chlorides and carbonates in it [65] (Table 6a). The positive correlation indicated influence of one parameter over other. However, during post-monsoon showed strong positive correlation among EC-TDS, TH- $\mathrm{Mg}^{2+}$ $\mathrm{Ca}^{2+}-\mathrm{HCO}_{3}{ }^{-}$indicating to the dissolution of limestone with the incoming water sources whereas positive correlation between $\mathrm{TH}-\mathrm{K}^{+}-\mathrm{SO}_{4}{ }^{2-}$ have distinctive resources (Table $6 \mathrm{~b}$ ).

\subsection{Principal Component Analysis (PCA)}

Table 7 represents the results of Kaiser-Meyer-Olkin (KMO) and Barlett's Test. The KMO test results were interpreted according to guiding rules [66], the value of 0.743 for Pre-Monsoon (PRM) and 0.718 value for Post-Monsoon (POM) indicates data adequacy for PCA. Another preliminary assumption test (Kolmogorov-Smirnov, KS, and Shapiro-Wilk, SW) was conducted to check the normality of dataset [67] using IBM SPSS Statistics 26 . The significant value for KS and SW test must be greater than 0.05 ( $p>0.05$ ). Results of computed $p$-value based on KS and SW is presented in Table 8 . All the dependent variables had $p$-value greater than 0.005 , it was therefore concluded that the data used is statistically normally distributed.

To distinguish the latent factors influencing the hydrochemistry, PCA was applied on analyzed parameters of surface water samples. Principal components (PCs) taken for interpretation having eigen values $>0.75$ and additionally second level of interpretation are considered statistically significant $[23,68]$. Table 9 shows the component loading factors, cumulative percentage and percentages of variance and communality explained by each principal component. Standardized datasets were employed for performing PCA and in varimax rotated component matrix only four PCs, whose eigen value is greater than 1, explained 81.17 and $77.64 \%$ of the total variance for pre-monsoon and post-monsoon period, respectively. A scree plot representing all the PCs which were extracted during PCA is shown in Fig. 7 ( $a \& b)$.

During the pre-monsoon period, PC1 explains approximately $1 / 3$ rd i.e., $30.35 \%$ of the total variance and has strong positive correlation value with Total Hardness, $\mathrm{Mg}^{2+}$ and $\mathrm{HCO}_{3}{ }^{-}$and a moderately strong positive correlation with $\mathrm{Na}^{+}$ and $\mathrm{Cl}^{-}$which reflects the role of lithogenic factors in influencing the water chemistry [69]. High-positive loading of $\mathrm{Mg}^{2+}$ and $\mathrm{HCO}_{3}{ }^{-}$with TH shows temporary hardness in the water. Strong correlation of $\mathrm{HCO}_{3}{ }^{-}$ions with alkali and alkaline earth metals indicated the natural weathering sources $[69,70]$. PC2 (25.30\% of total variance) has moderate positive 
Table 6 a: Matrix of correlation for water variables during pre-monsoon. b: Matrix of correlation for water variables during post-monsoon

\begin{tabular}{|c|c|c|c|c|c|c|c|c|c|c|c|c|}
\hline & $\mathrm{pH}$ & EC & TDS & $\mathrm{TH}$ & $\mathrm{Mg}^{2+}$ & $\mathrm{Ca}^{2+}$ & $\mathrm{K}+$ & $\mathrm{Na}^{+}$ & $\mathrm{Cl}^{-}$ & $\mathrm{HCO}^{-}$ & $\mathrm{SO}_{4}{ }^{2-}$ & $\mathrm{NO}^{-}$ \\
\hline \multicolumn{13}{|l|}{ (a) } \\
\hline $\mathrm{pH}$ & 1.00 & & & & & & & & & & & \\
\hline EC & -0.58 & 1.00 & & & & & & & & & & \\
\hline TDS & -0.58 & 1.00 & 1.00 & & & & & & & & & \\
\hline $\mathrm{TH}$ & 0.03 & 0.20 & 0.20 & 1.00 & & & & & & & & \\
\hline $\mathrm{Mg}^{2+}$ & 0.07 & 0.19 & 0.19 & 0.98 & 1.00 & & & & & & & \\
\hline $\mathrm{Ca}^{2+}$ & 0.03 & 0.04 & 0.04 & 0.54 & -0.14 & 1.00 & & & & & & \\
\hline $\mathrm{K}+$ & 0.18 & 0.19 & 0.19 & -0.18 & -0.23 & 0.31 & 1.00 & & & & & \\
\hline $\mathrm{Na}^{+}$ & 0.25 & -0.22 & -0.22 & 0.34 & 0.32 & 0.01 & 0.14 & 1.00 & & & & \\
\hline $\mathrm{Cl}^{-}$ & 0.25 & 0.12 & 0.12 & 0.34 & 0.32 & 0.01 & 0.14 & 1.00 & 1.00 & & & \\
\hline $\mathrm{HCO}^{-}$ & -0.07 & -0.05 & -0.05 & 0.79 & 0.77 & -0.07 & 0.08 & 0.61 & 0.61 & 1.00 & & \\
\hline $\mathrm{SO}_{4}{ }^{2-}$ & 0.28 & 0.15 & 0.15 & 0.20 & -0.13 & -0.15 & -0.47 & -0.26 & -0.26 & -0.15 & 1.00 & \\
\hline $\mathrm{NO}^{-}$ & 0.09 & -0.13 & -0.13 & -0.14 & -0.14 & 0.06 & 0.03 & -0.27 & -0.27 & -0.19 & -0.14 & 1.00 \\
\hline \multicolumn{13}{|l|}{ (b) } \\
\hline $\mathrm{pH}$ & 1.00 & & & & & & & & & & & \\
\hline $\mathrm{EC}$ & 0.11 & 1.00 & & & & & & & & & & \\
\hline TDS & 0.11 & 1.00 & 1.00 & & & & & & & & & \\
\hline $\mathrm{TH}$ & 0.14 & 0.38 & 0.38 & 1.00 & & & & & & & & \\
\hline $\mathrm{Mg}^{2+}$ & 0.05 & 0.08 & 0.08 & 0.94 & 1.00 & & & & & & & \\
\hline $\mathrm{Ca}^{2+}$ & 0.08 & 0.61 & 0.61 & 0.82 & -0.15 & 1.00 & & & & & & \\
\hline $\mathrm{K}+$ & 0.24 & 0.20 & 0.20 & 0.62 & 0.49 & 0.33 & 1.00 & & & & & \\
\hline $\mathrm{Na}^{+}$ & 0.37 & 0.24 & 0.24 & 0.20 & 0.20 & 0.03 & -0.11 & 1.00 & & & & \\
\hline $\mathrm{Cl}^{-}$ & 0.01 & 0.58 & 0.58 & 0.32 & 0.15 & 0.36 & 0.17 & 0.32 & 1.00 & & & \\
\hline $\mathrm{HCO}_{3}^{-}$ & 0.06 & 0.15 & 0.15 & 0.84 & 0.73 & 0.18 & 0.51 & -0.17 & 0.17 & 1.00 & & \\
\hline $\mathrm{SO}_{4}{ }^{2-}$ & 0.39 & 0.29 & 0.29 & 0.60 & 0.36 & 0.32 & 0.15 & 0.02 & 0.42 & 0.28 & 1.00 & \\
\hline $\mathrm{NO}_{3}^{-}$ & -0.32 & 0.39 & 0.39 & 0.16 & 0.12 & 0.10 & 0.24 & -0.10 & 0.02 & 0.13 & -0.03 & 1.00 \\
\hline
\end{tabular}

Table 7 Kaiser-Meyer-Olkin and Barlett's test

\begin{tabular}{llll}
\hline KMO and Barlett's test & & PRM & POM \\
\hline KMO sampling adequacy & & 0.743 & 0.718 \\
Barlett's Test of Spherecity & Approx. Chi-Square & 913.12 & 848.67 \\
& df & 66 & 66 \\
& Sig & 0 & 0 \\
\hline
\end{tabular}

correlation with $\mathrm{Na}^{+}$and $\mathrm{Cl}^{-}$and strong negative correlation with $\mathrm{EC}$ and TDS. Different hydrogeochemical processes that contribute to enrich more mineralized water is due to the combinations of $\mathrm{Na}^{+}, \mathrm{Cl}^{-}, \mathrm{HCO}_{3}{ }^{-}, \mathrm{SO}_{4}{ }^{-}$ions. $\mathrm{PC} 3$ was strongly positive weighted on $\mathrm{Ca}^{2+}$ and $\mathrm{K}^{+}$and moderate positive score on $\mathrm{Na}^{+}$accounts for $16.37 \%$. PC4 explains $9.15 \%$ of the total variance observed and has strong positive correlation with $\mathrm{NO}_{3}{ }^{-}$which points towards the role of agricultural runoff (NPK) along with the seepage of wastewater into the surface water bodies.

For post-monsoon period, again PC1 explains 1/3rd i.e., $34.32 \%$ of the total variance and has a strong positive loading with $\mathrm{EC}, \mathrm{TDS}$ and $\mathrm{TH}$ and a moderately positive correlation with $\mathrm{Ca}^{2+}, \mathrm{K}^{+}, \mathrm{HCO}_{3}{ }^{-}$and $\mathrm{Cl}^{-}$. The high positive correlation of $\mathrm{Mg}^{2+}$ with total hardness shows temporary hardness [71] indicated that with the high concentration of $\mathrm{Mg}^{2+}$ ions the degree of water hardness increases. A high positive loading of $\mathrm{Ca}^{2+}$ and $\mathrm{HCO}_{3}{ }^{-}$is attributed to various natural processes such as- weathering of rock minerals (limestone and calcium carbonate bearing rocks) and to various ion-exchange processes taking place in the groundwater system [69]. PC2 exhibits $18.39 \%$ of the total variance and the values of $\mathrm{Mg}^{2+}$ show high loading and the concentration of $\mathrm{HCO}_{3}{ }^{-}$has moderate positive loading on the PC2 (Table 7). PC3 shows the $15.73 \%$ of the total variance with moderate positive loading on $\mathrm{Na}^{+}$, moderate negative score on $\mathrm{NO}_{3}{ }^{-}$. The significant 
Table 8 Results of the normality tests

\begin{tabular}{|c|c|c|c|}
\hline Parameters & Seasons & $\begin{array}{l}\text { Kolmogorov-Smirnov } \\
\text { Statistic }\end{array}$ & $\begin{array}{l}\text { Shapiro-Wilk } \\
\text { Statistic }\end{array}$ \\
\hline \multirow[t]{2}{*}{$\mathrm{pH}$} & Pre-monsoon & 0.241 & 0.784 \\
\hline & Post-monsoon & 0.189 & 0.684 \\
\hline \multirow[t]{2}{*}{ EC } & Pre-monsoon & 0.221 & 0.842 \\
\hline & Post-monsoon & 0.162 & 0.724 \\
\hline \multirow[t]{2}{*}{ TDS } & Pre-monsoon & 0.228 & 0.864 \\
\hline & Post-monsoon & 0.178 & 0.836 \\
\hline \multirow[t]{2}{*}{ TH } & Pre-monsoon & 0.321 & 0.848 \\
\hline & Post-monsoon & 0.247 & 0.764 \\
\hline \multirow[t]{2}{*}{$\mathrm{Mg}^{2+}$} & Pre-monsoon & 0.411 & 0.807 \\
\hline & Post-monsoon & 0.198 & 0.758 \\
\hline \multirow[t]{2}{*}{$\mathrm{Ca}^{2+}$} & Pre-monsoon & 0.172 & 0.784 \\
\hline & Post-monsoon & 0.203 & 0.842 \\
\hline \multirow[t]{2}{*}{$\mathrm{K}^{+}$} & Pre-monsoon & 0.264 & 0.812 \\
\hline & Post-monsoon & 0.118 & 0.784 \\
\hline \multirow[t]{2}{*}{$\mathrm{Na}^{2+}$} & Pre-monsoon & 0.246 & 0.846 \\
\hline & Post-monsoon & 0.212 & 0.889 \\
\hline \multirow[t]{2}{*}{$\mathrm{Cl}^{-}$} & Pre-monsoon & 0.354 & 0.742 \\
\hline & Post-monsoon & 0.254 & 0.668 \\
\hline \multirow[t]{2}{*}{$\mathrm{HCO}_{3}^{-}$} & Pre-monsoon & 0.347 & 0.824 \\
\hline & Post-monsoon & 0.244 & 0.864 \\
\hline \multirow[t]{2}{*}{$\mathrm{SO}_{4}{ }^{2-}$} & Pre-monsoon & 0.504 & 0.802 \\
\hline & Post-monsoon & 0.482 & 0.794 \\
\hline \multirow[t]{2}{*}{$\mathrm{NO}_{3}{ }^{-}$} & Pre-monsoon & 0.248 & 0.862 \\
\hline & Post-monsoon & 0.164 & 0.801 \\
\hline
\end{tabular}

Table 9 Varimax rotated matrix of analyzed water samples of Parbati River

\begin{tabular}{|c|c|c|c|c|c|c|c|c|c|c|}
\hline \multirow[t]{2}{*}{ Variables } & \multicolumn{5}{|c|}{ Component (pre-monsoon) } & \multirow[b]{2}{*}{ PC1 } & \multicolumn{4}{|c|}{ Component (post-monsoon) } \\
\hline & PC1 & PC2 & PC3 & PC4 & Communality & & PC2 & PC3 & PC4 & Communality \\
\hline $\mathrm{pH}$ & -0.302 & 0.735 & 0.147 & -0.044 & 0.656 & -0.078 & 0.275 & 0.811 & -0.127 & 0.756 \\
\hline EC & 0.236 & -0.899 & 0.072 & -0.192 & 0.907 & 0.757 & -0.587 & 0.004 & 0.089 & 0.925 \\
\hline TDS & 0.236 & -0.899 & 0.072 & -0.192 & 0.907 & 0.757 & -0.587 & 0.004 & 0.089 & 0.925 \\
\hline $\mathrm{TH}$ & 0.881 & -0.084 & -0.327 & 0.212 & 0.931 & 0.851 & 0.451 & 0.017 & 0.083 & 0.935 \\
\hline $\mathrm{Mg}^{2+}$ & 0.869 & -0.069 & -0.427 & 0.173 & 0.972 & 0.584 & 0.703 & -0.012 & 0.334 & 0.947 \\
\hline $\mathrm{Ca}^{2+}$ & -0.161 & -0.051 & 0.559 & 0.126 & 0.357 & 0.604 & -0.431 & 0.054 & -0.468 & 0.773 \\
\hline $\mathrm{K}^{+}$ & 0.018 & -0.257 & 0.767 & 0.079 & 0.661 & 0.607 & 0.312 & -0.462 & -0.067 & 0.682 \\
\hline $\mathrm{Na}^{+}$ & 0.689 & 0.565 & 0.438 & -0.138 & 0.934 & 0.207 & -0.114 & 0.632 & 0.654 & 0.883 \\
\hline $\mathrm{Cl}^{-}$ & 0.669 & 0.525 & 0.438 & -0.138 & 0.934 & 0.583 & -0.232 & 0.345 & -0.006 & 0.513 \\
\hline $\mathrm{HCO}_{3}^{-}$ & 0.872 & 0.253 & -0.064 & 0.143 & 0.845 & 0.594 & 0.554 & -0.183 & -0.169 & 0.721 \\
\hline $\mathrm{SO}_{4}{ }^{2-}$ & -0.368 & 0.425 & -0.596 & -0.272 & 0.744 & 0.564 & 0.178 & 0.446 & -0.407 & 0.712 \\
\hline $\mathrm{NO}_{3}^{-}$ & -0.312 & -0.037 & 0.017 & 0.892 & 0.894 & 0.346 & -0.237 & -0.512 & 0.315 & 0.537 \\
\hline Eigen value & 3.642 & 3.036 & 1.966 & 1.098 & & 4.119 & 2.207 & 1.888 & 1.095 & \\
\hline $\begin{array}{l}\text { Cumulative } \% \\
\text { of variance }\end{array}$ & 30.351 & 55.651 & 72.03 & 81.181 & & 34.32 & 52.71 & 68.44 & 77.56 & \\
\hline$\%$ of variance & 30.351 & 25.301 & 16.379 & 9.151 & & 34.32 & 18.391 & 15.732 & 9.123 & \\
\hline
\end{tabular}




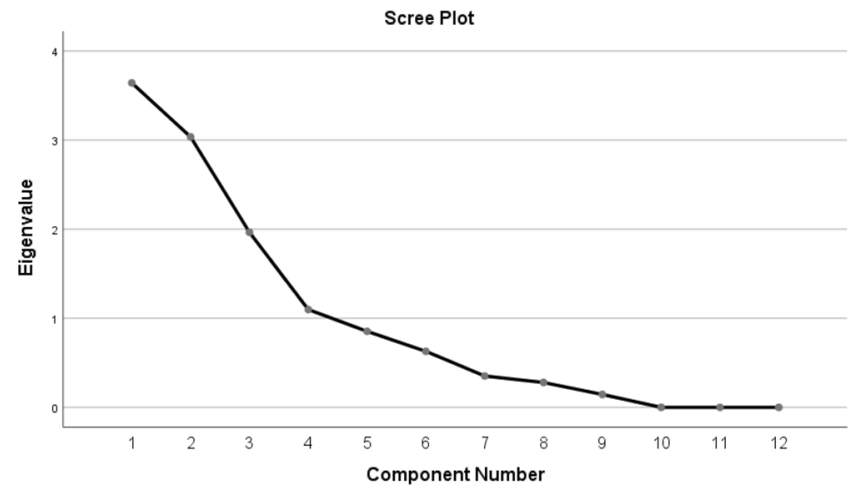

(a) Pre monsoon

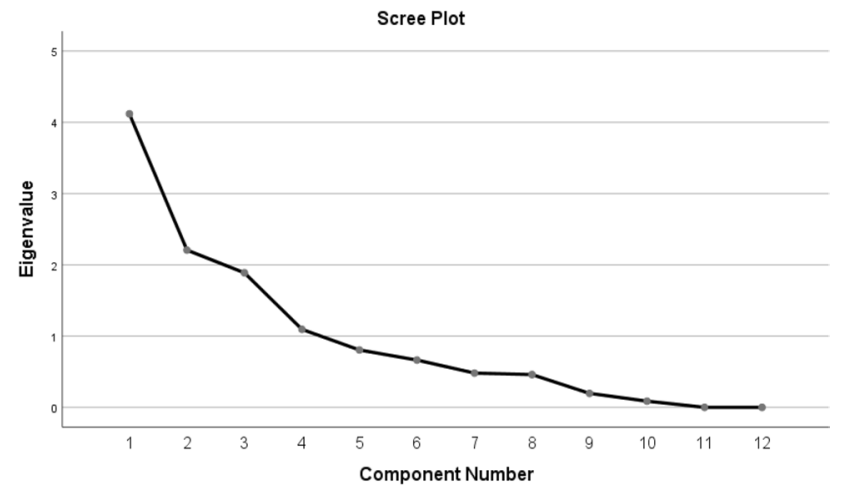

(b) Post monsoon

Fig.7 Scree plot extraction principal component in Pre monsoon and Post monsoon. a Pre monsoon. b Post monsoon

inverse relationship between $\mathrm{Na}^{+}$and $\mathrm{NO}_{3}{ }^{-}$indicates the diverse source of chemical origin [72]. $\mathrm{PC} 4$ explains $9.1 \%$ of the total variance observed and has strong positive correlation value with $\mathrm{Na}^{+}$and moderately strong negative correlation with $\mathrm{Ca}^{2+}$.

\subsection{Cluster analysis}

Cluster analysis is applied to obtain common cluster of monitoring locations having relatively similar characterstics. Dendrogram representing the clusters rendered during the analysis are shown in Fig. 8. Three clusters were obtained from pre-monsoon and post-monsoon from the criteria of significant Square Euclidean distance measure of standardized data by applying a complete linkage method. In pre-monsoon cluster 1 consist of monitoring locations Nhyarathach, Kasol and Bhunter (1,9, and 18). Cluster 2 consist of monitoring location Rudranag, Guwacha, Barshaini, Manikaran bridge, Manikaran NHPC, Grahan nalla, Katagla, Malana-Jari, Charod and Hathithan (2, 3, 5, 6, 7, 8, 10, 12, 15 and 17). Cluster 3 consist of Toshnalla, Sumaropa, Shat nalla, Shat -Parvati confluence and Jiyah(4, 11, 13, 14 and 16). In Post-monsoon cluster 1 consist of Nhyarathach, Rudranag, Guwacha, Tosh nalla, Barshaini, Katagla, Sumaropa, Malana-Jari, Charod and Jiyah(1, 2, 3, 4, 5, 10,11, 12, 15 and 16). Cluster 2 consists of Malana-Jari and Kasol (9 and 12) and cluster 3 consist Manikaran bridge, Manikaran NHPC, Shat nalla, Bhunter confluence, Grahan nalla and Hathithan $(6,7,8,13,17$ and 18).

For both the pre-monsoon as well as post-monsoon seasons three significant clusters were found. All clusters formed have high similarity levels indicating the overall variability of parameters of different sampling points is low within the cluster. However, no specific intra-clusters trend was found to be significant during the analysis.

In the Table 10, average value of each variable is given for all the clusters for both pre-monsoon and post-monsoon seasons. During the pre-monsoon season cluster 1 exhibits the highest level for $\mathrm{TH}, \mathrm{Mg}^{2+}$, and $\mathrm{HCO}_{3}{ }^{-}$. Cluster 2 has
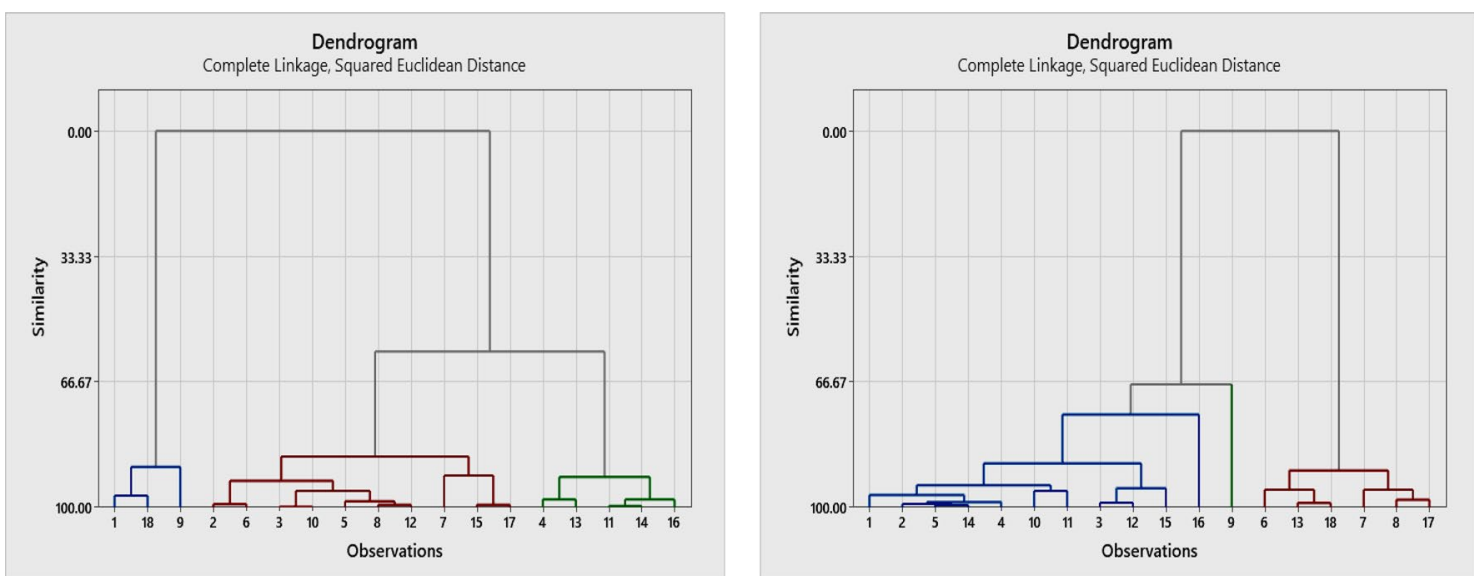

Fig.8 Hierarchical dendrogram showing agglomerate cluster grouping 
Table 10 Cluster Centroids for each parameter of analyzed water samples of Parbati River

\begin{tabular}{|c|c|c|c|c|c|c|c|c|}
\hline \multicolumn{5}{|c|}{ Pre-monsoon } & \multicolumn{4}{|c|}{ Post-monsoon } \\
\hline Variable & Cluster 1 & Cluster 2 & Cluster 3 & Grand Centroid & Cluster 1 & Cluster 2 & Cluster 3 & Grand Centroid \\
\hline $\mathrm{pH}$ & 7.717 & 7.534 & 7.8800 & 7.661 & 6.765 & 6.998 & 6.750 & 6.842 \\
\hline EC & 93.333 & 94.200 & 92.0000 & 93.444 & 162.951 & 165.369 & 191.138 & 165.323 \\
\hline TDS & 58.800 & 59.346 & 57.9600 & 58.870 & 105.918 & 107.490 & 124.240 & 107.460 \\
\hline $\mathrm{TH}$ & 121.333 & 98.398 & 73.7097 & 95.362 & 111.348 & 177.023 & 133.170 & 134.452 \\
\hline $\mathrm{Mg}^{2+}$ & 18.938 & 13.398 & 7.2972 & 12.627 & 17.858 & 20.027 & 20.824 & 18.745 \\
\hline $\mathrm{Ca}^{2+}$ & 17.382 & 17.326 & 17.4938 & 17.382 & 26.773 & 24.310 & 22.320 & 25.705 \\
\hline $\mathrm{K}^{+}$ & 3.633 & 3.870 & 3.7600 & 3.800 & 3.873 & 3.767 & 4.200 & 3.856 \\
\hline $\mathrm{Na}^{+}$ & 2.800 & 2.660 & 2.3600 & 2.600 & 3.200 & 3.667 & 4.000 & 3.400 \\
\hline $\mathrm{Cl}^{-}$ & 3.976 & 3.777 & 3.3512 & 3.692 & 1.123 & 0.781 & 0.710 & 0.986 \\
\hline $\mathrm{HCO}_{3}^{-}$ & 162.667 & 125.050 & 91.5000 & 122.000 & 182.995 & 181.333 & 168.000 & 181.608 \\
\hline $\mathrm{SO}_{4}{ }^{2-}$ & 2.743 & 2.375 & 2.9212 & 2.588 & 2.506 & 2.628 & 2.680 & 2.557 \\
\hline $\mathrm{NO}_{3}^{-}$ & 1.233 & 1.262 & 1.3480 & 1.281 & 1.555 & 1.450 & 1.640 & 1.525 \\
\hline
\end{tabular}

lowest level of $\mathrm{pH}$ as well as $\mathrm{SO}_{4}{ }^{-}$and highest level of TDS. Cluster 3 has highest value for $\mathrm{pH}_{1} \mathrm{SO}_{4}{ }^{-}$and $\mathrm{NO}_{3}{ }^{-}$and least value for $\mathrm{EC}, \mathrm{TDS}, \mathrm{TH}, \mathrm{Mg}^{2+}$ and $\mathrm{HCO}_{3}{ }^{-}$.

In the post-monsoon season, Cluster 1 exhibit lowest levels of $\mathrm{EC}, \mathrm{TDS}, \mathrm{TH}, \mathrm{Mg}^{2+}, \mathrm{Na}^{+}$and $\mathrm{SO}_{4}{ }^{-}$On the other hand, cluster 2 has highest levels of $\mathrm{pH}$ and $\mathrm{TH}$, however, the overall $\mathrm{pH}$ of water samples during the post-season is lower than the pre-monsoon season. Cluster 3 has highest value for $\mathrm{EC}, \mathrm{TDS}, \mathrm{Mg}, \mathrm{K}, \mathrm{Na}$ and $\mathrm{NO}_{3}{ }^{-}$.

\section{Conclusion}

Usefulness of multivariate statistical methods along with WQI and graphical representation techniques is well illustrated in the present study. In the present study such tools are employed for understanding the physio-chemical characterization of river water system of Parbati river basin. The physicochemical parameters of all the analyzed water samples are well within the desirable limits prescribed by BIS (2012) and WHO (2011). Therefore, the water quality is suitable for domestic purposes, except for the few locations where $\mathrm{pH}$ was beyond the permissible range in pre-monsoon season. Piper and Durov plot classified $100 \%$ of samples were of $\mathrm{Ca}^{2+}-\mathrm{Mg}^{2+}-\mathrm{HCO}_{3}^{-}$water types indicating temporary hardness in both the seasons. Dominance of alkaline earth metals over that of alkalis and of weak acidic anions over that of strong acidic anions is well represented in the Piper cross plots. Moreover, Piper cross plots also highlighted the natural geochemical processes such as- weathering and dissolution of minerals. The results of Gibbs diagram indicated that the chemical composition of surface water in the Parbati river basin is strongly influenced by rock dominance, weathering of silicates in pre monsoon whereas dominance of rock is followed by precipitation in post monsoon season. The WQI shows maximum water samples were falling in good class followed by excellent in both the seasons. PCA and CA identifies the major factors influencing the surface water chemistry such as- rock-water interaction, ion exchange and leaching of parent materials as well as dominant anthropogenic factors like agri-runoff and domestic waste water runoff.

Acknowledgements Authors are grateful to the Director, G.B. Pant National Institute of Himalayan Environment (NIHE), Kosi-Katarmal, Almora, Uttarakhand for providing necessary facilities in in the Institute which could make the present study possible. Authors are also thankful to the Mountain Division of Institute for providing financial support.

Author contributions Authors G.S., N.T. and V.B. contributed in data collection, analysis and drafting the manuscript. While corresponding author R.L. contributed in terms of conception or design of the manuscript and finalizing the manuscript. Whereas, Author J.C.K.\& K.K. contributed in critical revision of the article and final approval of the manuscript to be published.

Funding This research was funded by Mountain Division, 5th Division of G B Pant National Institute of Himalayan Environment, Kosi-Katarmal, Almora, Uttarakhand, India.

Data availability The datasets generated during and/or analyzed during the current study is available from the corresponding author on reasonable request. 


\section{Declaration}

Competing interests All the authors declare that there is no competing economic interests or personal connections that could have appeared to impact the work reported in this manuscript.

Open Access This article is licensed under a Creative Commons Attribution 4.0 International License, which permits use, sharing, adaptation, distribution and reproduction in any medium or format, as long as you give appropriate credit to the original author(s) and the source, provide a link to the Creative Commons licence, and indicate if changes were made. The images or other third party material in this article are included in the article's Creative Commons licence, unless indicated otherwise in a credit line to the material. If material is not included in the article's Creative Commons licence and your intended use is not permitted by statutory regulation or exceeds the permitted use, you will need to obtain permission directly from the copyright holder. To view a copy of this licence, visit http://creativecommons.org/licenses/by/4.0/.

\section{References}

1. Grimm NB, Faeth SH, Golubiewski NE, Redman CL, Wu J, Bai X, Briggs JM. Global change and the ecology of cities. Science. 2008;319(5864):756-60.

2. Shiklomanov IA. Appraisal and assessment of world water resources. Water Int. 2000;25(1):11-32.

3. Singh S, Tanvir Hassan SM, Hassan M, Bharti N. Urbanisation and water insecurity in the Hindu Kush Himalaya: insights from Bangladesh, India, Nepal and Pakistan. Water Policy. 2020;22(S1):9-32.

4. Santucci L, Carol E, Tanjal C. Industrial waste as a source of surface and groundwater pollution for more than half a century in a sector of the Río de la Plata coastal plain (Argentina). Chemosphere. 2018;206:727-35.

5. Matta G, Kumar A, Naik PK, Kumar A, Srivastava N. Assessment of heavy metals toxicity and ecological impact on surface water quality using HPI in Ganga river. INAE Lett. 2018;3(3):123-9.

6. Kumar P, Mahajan AK, Kumar A. Groundwater geochemical facie: implications of rock-water interaction at the Chamba city (HP), northwest Himalaya, India. Environ Sci Pollut Res. 2019;16:1-5.

7. Porcella DB, Sorensen DL. Characteristics of nonpoint source urban runoff and its effects on stream ecosystems. Corvallis Environmental Research Laboratory, Office of Research and Development, US Environmental Protection Agency; 1980.

8. Dalai TK, Krishnaswami S, Sarin MM. Major ion chemistry in the headwaters of the Yamuna river system: chemical weathering, its temperature dependence and CO2 consumption in the Himalaya. Geochimical et Cosmochimica Acta. 2002;66(19):3397-416.

9. Jiang L, Yao Z, Liu Z, Wang R, Wu S. Hydrochemistry and its controlling factors of rivers in the source region of the Yangtze River on the Tibetan Plateau. J Geochem Explor. 2015;1(155):76-83.

10. Sarkar A, Paul B. The global menace of arsenic and its conventional remediation-A critical review. Chemosphere. 2016;1 (158):37-49.

11. Shanmuganandan $S$. Water quality, water resources and health water quality in relation to human health: a study with reference to water-borne diseases and major environmental issues in India subcontinent. Working paper, Madurai Kamaraj University; 1999.

12. DeNormandie J, Sunita J. Combating diarrhoeal disease in India through safe drinking water. World Health Organisation (WHO); 2002. http://www.who.int/mediacentre/multimedia/2002/ind_sanitation/en/index.htmL.

13. Rani S, Sreekesh S. Evaluating the responses of streamflow under future climate change scenarios in a Western Indian Himalaya Watershed. Environ Process. 2019;6(1):155-74.

14. Thakur N, Rishi M, Sharma DA, Keesari T. Quality of water resources in Kullu Valley in Himachal Himalayas, India: perspective and prognosis. Appl Water Sci. 2018;8(1):1-3.

15. District Disaster Management Plan (DDMP). Kullu district, Himachal Pradesh, India; 2011

16. Thakur N, Rishi M, Keesari T, Sharma DA, Sinha UK. Assessment of recharge source to springs in upper Beas basin of Kullu region, Himachal Pradesh, India using isotopic signatures. J Radioanal Nucl Chem. 2020;323(3):1217-25.

17. Maurya $P$, Kumari R, Mukherjee $S$. Hydrochemistry in integration with stable isotopes $(\delta 180$ and $\delta D)$ to assess seawater intrusion in coastal aquifers of Kachchh district, Gujarat, India. J Geochem Explor. 2019;196:42-56.

18. Adimalla N, Li P, Qian H. Evaluation of groundwater contamination for fluoride and nitrate in semi-arid region of Nirmal Province, South India: a special emphasis on human health risk assessment (HHRA). Hum Ecol Risk assess Int J. 2018;25(5):1107-24.

19. Herojeet R, Rishi MS, Lata R, Dolma K. Quality characterization and pollution source identification of surface water using multivariate statistical techniques, Nalagarh Valley, Himachal Pradesh, India. Appl Water Sci. 2017;7(5):2137-56.

20. Khanday SA, Romshoo SA, Jehangir A, Sahay A, Chauhan P. Environmetric and GIS techniques for hydrochemical characterization of the Dal lake, Kashmir Himalaya, India. Stoch Env Res Risk Assess. 2018;32(11):3151-68.

21. Zhao Y, Xia XH, Yang ZF, Wang F. Assessment of water quality in Baiyangdian Lake using multivariate statistical techniques. Procedia Environ Sci. 2012;13:1213-26.

22. Simeonov V, Stratis JA, Samara C, Zachariadis G, Voutsa D, Anthemidis A, Sofoniou M, Kouimtzis T. Assessment of the surface water quality in Northern Greece. Water Res. 2003;37(17):4119-24.

23. Herojeet R, Rishi MS, Lata R, Sharma R. Application of environmetrics statistical models and water quality index for groundwater quality characterization of alluvial aquifer of Nalagarh Valley, Himachal Pradesh, India. Sustain Water Resour Manag. 2016;2(1):39-53.

24. Central Ground Water Board (CGWB). Groundwater information Booklet Kullu district Himachal Pradesh. Ministry of Water Resources, Government of India; 2013.

25. Choubey VM, Mukherjee PK, Bajwa BS, Walia V. Geological and tectonic influence on water-soil-radon relationship in Mandi-Manali area, Himachal Himalaya. Environ Geol. 2007;52(6):1163-71.

26. Geological Survey of India. Geothermal; atlas of India (Special Publication no.19). 1991. 
27. Srikantia SV, Bhargava ON. Geology of Himachal Pradesh. Geological society of India; 1998;2(1). ISBN No: 978-81-85867-32-1.

28. Biswas SS. Analysis of GIS based morphometric parameters and hydrological changes in Parbati River Basin, Himachal Pradesh, India. J Geogr Nat Disasters. 2016;6(175):2167-587.

29. Environment Impact Assessment report of Parbati Hydro Electric Project. NHPC limited, District-Kullu (Himachal Pradesh), India; 2005

30. APHA. Standards methods for the examination of water and waste water. 23rd ed. Washington DC: American Public Health Association; 2017.

31. Hounslow AW. Water quality data: analysis and interpretation. CRC Press; 2018.

32. Khalid S. An assessment of groundwater quality for irrigation and drinking purposes around brick kilns in three districts of Balochistan province, Pakistan, through water quality index and multivariate statistical approaches. J Geochem Explor. 2019;197:14-26.

33. Horton RK. An index-number system for rating water quality. Journal of Water Pollution Control Federation. 1965;37(3): 300-6.

34. Brown RM, McClelland NI, Deininger RA, Tozer RG. A Water Quality Index: Do We Dare? Water Sewage Works. 1970;117(10):339-43.

35. Matta G, Kumar A, Nayak A, Kumar P, Kumar A, Tiwari AK. Determination of water quality of Ganga River System in Himalayan region, referencing indexing techniques. Arab J Geosci. 2020;13(19):1-1.

36. Piper AM. A graphic procedure in the geochemical interpretation of water-analyses. EOS Trans Am Geophys Union. 1944;6:914-28.

37. Durov SA. Natural waters and graphic representation of their composition. In Dokl Akad Nauk SSSR. 1948;59(3):87-90.

38. Gibbs RJ. Mechanisms controlling world water chemistry. Science. 1970;170(3962):1088-90.

39. Noori R, Sabahi MS, Karbassi AR, Baghvand A, Zadeh HT. Multivariate statistical analysis of surface water quality based on correlations and variations in the data set. Desalination. 2010;260(1-3):129-36.

40. Hamid A, Bhat SA, Bhat SU, Jehangir A. Environmetric techniques in water quality assessment and monitoring: a case study. Environ Earth Sci. 2016;75(4):321.

41. Jung KY, Lee KL, Im TH, Lee IJ, Kim S, Han KY, Ahn JM. Evaluation of water quality for the Nakdong River watershed using multivariate analysis. Environ Technol Innov. 2016;5:67-82.

42. Kim JH, Kim RH, Lee J, Cheong TJ, Yum BW, Chang HW. Multivariate statistical analysis to identify the major factors governing groundwater quality in the coastal area of Kimje, South Korea. Hydrol Process Int J. 2005;19(6):1261-76.

43. Barzegar R, Moghaddam AA, Tziritis E, Adamowski J, Nassar JB, Noori M, Kazemian N. Exploring the hydrogeochemical evolution of cold and thermal waters in the Sarein-Nir area, Iran using stable isotopes $(\delta 180$ and $\delta D)$, geothermometry and multivariate statistical approaches. Geothermics. 2020;85:101815.

44. Singh KP, Malik A, Sinha S, Singh VK, Murthy RC. Estimation of source of heavy metal contamination in sediments of Gomti River (India) using principal component analysis. Water Air Soil Pollut. 2005;166(1):321-41.

45. Helena B, Pardo R, Vega M, Barrado E, Fernandez JM, Fernandez L. Temporal evolution of groundwater composition in an alluvial aquifer (Pisuerga River, Spain) by principal component analysis. Water Res. 2000;34(3):807-16.

46. Vieira JS, Pires JC, Martins FG, Vilar VJ, Boaventura RA, Botelho CM. Surface water quality assessment of Lis river using multivariate statistical methods. Water Air Soil Pollut. 2012;223(9):5549-61.

47. Liu CW, Lin KH, Kuo YM. Application of factor analysis in the assessment of groundwater quality in a blackfoot disease area in Taiwan. Sci Total Environ. 2003;313(1-3):77-89.

48. Ouyang Y. Evaluation of river water quality monitoring stations by principal component analysis. Water Res. 2005;39(12):2621-35.

49. Radelyuk I, Tussupova K, Persson M, Zhapargazinova K, Yelubay M. Assessment of groundwater safety surrounding contaminated water storage sites using multivariate statistical analysis and Heckman selection model: a case study of Kazakhstan. Environ Geochem Health. 2021;43(2):1029-50.

50. Likas A, Vlassis N, Verbeek JJ. The global k-means clustering algorithm. Pattern Recogn. 2003;36(2):451-61.

51. Edition F. Guidelines for drinking-water quality. WHO Chron. 2011;38(4):104-8.

52. BIS, I. S. D. W. S. Bureau of Indian Standards. New Delhi. 2012;2-3.

53. Sawyer CN, McCarty PL. Chemistry for sanitary engineers. 2nd ed. McGraw-Hill, New York. 1967.

54. Davis SN, De Weist RJM. Hydrogeology. John Wiley and Sons, New York. 1966.

55. Williams EL, Szramek KJ, Jin L, Ku TC, Walter LM. The carbonate system geochemistry of shallow groundwater-surface water systems in temperate glaciated watersheds (Michigan, USA): significance of open-system dolomite weathering. Geol Soc Am Bull. 2007;119(5-6):515-28.

56. Awadh SM, Ahmed RM. Hydrochemistry and pollution probability of selected sites along the Euphrates River, Western Iraq. Arab J Geosci. 2013;6(7):2501-18.

57. Gaglioti S, Infusino E, Caloiero T, Callegari G, Guagliardi I. Geochemical characterization of spring waters in the Crati river basin, Calabria (Southern Italy). Geofluids. 2019;2019:1-16.

58. Back W. Hydrochemical facies and ground-water flow patterns in Northern Atlantic Coastal Plain. AAPG Bull. 1960;44(7):1244-5.

59. Chadha DK. A proposed new diagram for geochemical classification of natural waters and interpretation of chemical data. Hydrogeol J. 1999;7(5):431-9.

60. Ravikumar P, Somashekar RK, Prakash KL. A comparative study on usage of Durov and Piper diagrams to interpret hydrochemical processes in groundwater from SRLIS river basin, Karnataka, India. Elixir Earth Sci. 2015;2015(80):31073-7.

61. Lloyd JW, Heathcote JA. Natural inorganic hydrochemistry in relation to ground water. 1985.

62. Bhat SA, Meraj G, Yaseen S, Pandit AK. Statistical assessment of water quality parameters for pollution source identification in Sukhnag stream: an inflow stream of lake Wular (Ramsar Site), Kashmir Himalaya. J Ecosyst. 2014;2014:1-18.

63. Gaury PK, Meena NK, Mahajan AK. Hydrochemistry and water quality of Rewalsar Lake of Lesser Himalaya, Himachal Pradesh, India. Environ Monit Assess. 2018;190(2):1-22.

64. Singh KP, Malik A, Mohan D, Sinha S. Multivariate statistical techniques for the evaluation of spatial and temporal variations in water quality of Gomti River (India)—a case study. Water Res. 2004;38(18):3980-92.

65. Husain MS, Umar R, Ahmad S. A comparative study of springs and groundwater chemistry of Beas and Parbati valley, Kullu District, Himachal Pradesh, India. HydroResearch. 2020;3:32-47.

66. Kaiser HF. An index of factorial simplicity. Psychometrika. 1974;39(1):31-6. 
67. Alves DD, Riegel RP, de Quevedo DM, Osório DM, da Costa GM, Do Nascimento CA, Telöken F. Seasonal assessment and apportionment of surface water pollution using multivariate statistical methods: Sinos River, southern Brazil. Environ Monit Assess. $2018 ; 190$ (7):1-2.

68. Shrestha S, Kazama F. Assessment of surface water quality using multivariate statistical techniques: a case study of the Fuji river basin, Japan. Environ Model Softw. 2007;22(4):464-75.

69. Okiongbo KS, Douglas RK. Evaluation of major factors influencing the geochemistry of groundwater using graphical and multivariate statistical methods in Yenagoa city, Southern Nigeria. Appl Water Sci. 2015;5(1):27-37.

70. Srivastava SK, Ramanathan AL. Geochemical assessment of groundwater quality in vicinity of Bhalswa landfill, Delhi, India, using graphical and multivariate statistical methods. Environ Geol. 2008;53(7):1509-28.

71. Boyd CE, Tucker CS. Water quality and pond soil analysis for aquaculture. Agricultural Experiment Station, Alabama. 1992.

72. Hickman RE, Gray BJ. Trends in the quality of water in New Jersey streams, water years 1998-2007. U. S. Geological Survey; 2010.

Publisher's Note Springer Nature remains neutral with regard to jurisdictional claims in published maps and institutional affiliations. 